\title{
An Empirical Analysis of Sovereign Credit Risk Co-movement between Japan and ASEAN Countries
}

\author{
Boonlert Jitmaneeroj ${ }^{1}$, John Ogwang ${ }^{2 *}$ \\ ${ }^{1}$ University of the Thai Chamber of Commerce, Bangkok, Thailand \\ ${ }^{2}$ Lira University, Lira, Uganda \\ *ogwangjb@gmail.com
}

\begin{abstract}
Japan is the most developed economy in Asia. However, it has been on record for being the most heavily indebted country among OECD countries. In many circumstances, the high sovereign debt level indicates a high possibility of sovereign credit risks associated with investment in government bond. The high sovereign credit risk may also generate a number of negative externalities for private businesses operating in the host country. This paper investigates whether sovereign credit risk of Japan as measured by its sovereign credit default swap (SCDS) can better predict and commove with sovereign credit risk of selected ASEAN countries. The bivariate VAR model was used to test for Granger Causalities among these countries SCDS premiums and correlation analysis to investigate co-movements between SCDS of these countries. The results indicate that Japan's sovereign credit risks do not co-move with those of ASEAN countries, Furthermore, Sovereign credit risks of ASEAN countries tend to lead those of Japan as evidenced by unidirectional causalities from these countries to Japan. The overall suggestion is that sovereign credit risk of Japan is not likely to influence those of ASEAN. The paper concludes with some implications for businesses.
\end{abstract}

Keywords: Sovereign credit risk, Credit Default Swap, Public debt sustainability, Co-movement, ASEAN, Japan

\section{Introduction}

The current fiscal situation of Japan characterized by a very high debt-to-GDP ratio which is currently about 229.2\% of GDP, coupled with a slowdown in economic growth and with increasing ageing problem hindering the productivity of Japan's labor force has attracted a lot of attention in literature. Being the third largest economy in the world with its currency in the basket of Special Drawing Rights, Japan's sovereign debt problems may culminate into a global crisis. International Monetary Fund (IMF 2011) expressed concerns about this scenario and a lot of academic papers including Doi and Okimoto (2011), Sakuragawa and Hosono (2011), suggest that drastic fiscal measures should be taken to stabilize Japan's public debts. The high public debt burdens with a slowdown in economic growth raises a lot of questions about Japan's sovereign credit worthiness. Nevertheless Hoshi and Ito (2014) argue that investors in Japan's government bonds perceive less sovereign credit risk as evidenced by low and stable yields on Japan's government bonds. The low and stable yields on Japan's government bonds are very significant in ensuring that public debt does not explode given the current growth slowdown. According to ECONOTE (2013), the low and stable yields on Japan's government bonds are due to the fact that a very high proportion of Japan's government bonds are held by domestic investors. As foreigners increase their holdings of Japans government bonds, the yields will definitely go up due to increased risks such as currency risks. Although there is little possibility for the outbreak of sovereign debt crises in Japan due to her heavy debt burden as argued by many commentators, there are growing concerns about sovereign credit risk associated with investment in Japan's government bonds. The sovereign rating downgrade of Japan by one notch to "A+" in September 2015 by S\&P is an indicator of increased perceived sovereign credit risks of Japanese government bonds.

Sovereign credit risk arises in a situation where government is not either able or willing to honor its debt obligations or the debts it guarantees. On the other hand, the ability of the government to service its debts depends on among other factors the macro-economic fundamentals such as growth rate, interest rates on its bond, fiscal deficit, current account balance, performance of financial sector, level of international reserves etc. While Japanese economy currently faces deterioration in growth rates and fiscal balance, its safety nets against sovereign credit risks comes from the strong financial system and international reserves that it holds. 
International reserve can make the servicing of foreign currency denominated debts easier. The analysis of sovereign credit risk of Japan especially now when it is struggling to accommodate its debt burdens is very significant to international businesses which always invest in Japanese government bonds. Moreover, there are many negative externalities that sovereign credit risks can generate to Multinational Corporations resident in the host country like Japan. The literature on Japan-ASEAN economic and financial interdependence is very rich and has a long history. The forum for synthetic rubber held in 1973 involving Japan and the original ASEAN countries and the subsequent promulgation of Fukuda doctrine in 1977 by the then prime minister of Japan Takeo Fukuda seems to be the foundation of Japan-ASEAN economic, financial and political corporation. According to Kawai, Thuzar and Hayton (2016), Japan is the oldest and the second largest trade partner of ASEAN. In 2014 the bilateral trade between Japan and ASEAN countries amounted to $\$ 220$ billion and a total of $\$ 180$ billion FDI stock inflows into ASEAN came from Japan. Moreover as indicated by Kawai et al. (2016), Japanese Multinational Corporations have many production bases in ASEAN with extensive supply chain networks of Japanese auto companies in ASEAN countries of Malaysia, Indonesia, and Thailand. The trade synchronization between ASEAN and Japan makes it easy for any deterioration in Japan's sovereign balance sheet to gear into ASEAN countries' sovereign balance sheets through the trade channels. It is important to investigate if Japan's sovereign credit risk can better predict the sovereign credit risks of some selected ASEAN countries and if they co move.

While many papers have concentrated on analyzing Japan's debt sustainability and its sovereign credit risks, very few papers have investigated the transmission and spillover of financial shocks between Japan and ASEAN countries. The few related papers worthy to mention includes Guimaraes and Hong (2016) which uses the return and volatility (equity market) spillover index of Diebold and Yilmaz (2009) and reveals that spillovers from advanced economies like Japan to other countries are on decline as compared to emerging Asian economies like China and South Korea which generate much transmissions to other countries. The paper further indicates that the increasing financial connectedness of emerging markets with other countries is being driven by among other factors the increasing weight of emerging markets in global portfolio. Cho, Choi and Chung (2014) which identify a stronger contagion effect among six Asian countries of Thailand, Indonesia, Philippines, China, Korea and Malaysia and weaker contagion effects between Japan and other six countries. Finally, Yoshizaki et al. (2013) which provides some evidence of mean spillover effects from European countries on Japan while Japan on the other hand had no mean transmission effects on European Union countries before the crisis. The paper thus contributes to existing literature by extending Cho et al. (2014) to provide some empirical evidence on the direction of causality for sovereign credit risks of Japan and those of selected ASEAN countries. As pointed out by Longstaff et al. (2011) and Cho et al. (2014), the knowledge of sovereign credit risk co-movement is very important to an MNC which invests in bonds of different countries as it will enable this MNC to properly manage its portfolio sovereign credit risks. Furthermore, as noted by Gunduz and Kaya (2013), such co-movements across countries indicate the possibility of other countries to be affected by the crises from one or some countries. Thus this study will provide some light on the likelihood of ASEAN countries being affected by the crises in Japan and vice-versa.

\section{Literature Review}

It is a traditional practice in literature to appreciate what other authors have contributed in the study of a particular subject. This section thus presents a brief review of literature on SCDS co-movement, sovereign credit risk and credit default swap. On the part of SCDS co-movement, existing literature have always shown a strong evidence of SCDS co-movement across countries. Stolbov (2014) studies the interconnectedness of SCDS spreads for the BRICS countries and selected Major European economies and finds that in both causality dimensions, the BRICS countries SCDS tend to lead those of major European economies except for Germany. The study of SCDS co-movement of 17 European countries (11 from Eurozone and 6 outside Eurozone) was conducted by Bucholz and Tonzer (2013). The finding of this study indicates a strong evidence of comovement among SCDS of these countries despite divergence in the nature of SCDS spreads. However, higher co-movement was noted among countries having the same macro-economic fundamentals. Kregzde and Murauskas (2015) study the SCDS spreads of Baltic countries (Estonia, Latvia and Lithuania) and find that SCDS spreads of these countries are highly interdependent. For Asian countries, the recent study by Cho et al. (2014) that investigates the spillover and contagion effects within Asian countries SCDS market and noted a high SCDS co-movement among emerging Asian countries. However, this study finds that Japan's SCDS co- 
movement with other emerging Asian countries remains very weak evidenced by the average correlation coefficients of only about 0.35 .

Some studies investigate the co-movement of SCDS market in relation to other financial markets. Nordern and Weber (2009) use VAR model to examine the lead-lag relationship among the CDS, stock and bond market and concludes that the stock market leads the CDS and bond changes and there were co-movement between CDS spreads and bond spreads for many firms. Coronado et al. (2012) study the causal linkage between SCDS, and stock markets index in Europe using VAR model and finds a strong connection between SCDS and stock markets. Specifically, stock market led the SCDS market for most countries in the sample. Longstaff et al. (2011) is one of the most cited papers in this respect. The paper investigates the determinants of sovereign default swap spreads for 26 countries and concludes that global factors are the main determinant of sovereign default swap spread. Consistent with Longstaff et al. (2011), other studies that had earlier empirically shown the significance of impacts of global factors on sovereign risks include Fontana and Scheicher (2010). Similarly, Wang et al. (2013) note that the sovereign CDS spread for emerging markets like Mexico, Brazil and some Latin America countries are linked to global indicators more strongly. However, Ang and Longstaff (2013) find that EU core economies are not significantly influenced by the global non EU factors but CDS prices for these economies were rather more sensitive to changes in the intra EU financial market variables. Some studies example Afonso et al. (2007), Canter and Packer (1996) emphasize the roles of country's macro-economic and fiscal variables as major determinant of sovereign credit rating. In fact Robinson (2015) confirms the significance of fiscal policy decision making and fiscal balance as very important issues in determining sovereign risks for South Africa. Heinz and Sun (2014) investigate the sovereign CDS spreads in Central Eastern and South Eastern Europe (CESEE) countries and found that the spreads were driven by factors falling broadly under three different categories of global investor sentiment proxied by the VIX index, Liquidity condition in the market proxied by the bid- ask spreads of SCDS prices and macro- economic fundamentals. The study finds that macroeconomic fundamentals especially government fiscal position matters a lot in determination of SCDS spreads.

Finally another controversial issue in this subject is whether SCDS spreads clearly represents the sovereign credit risks of a country. Shino and Takahashi (2010) analyze the sovereign credit default swap spreads of Japan and conclude that the SCDS spreads changes are due to other factors rather than the fiscal situation of Japan. The impact of global factors as pointed by Longstaff et al. (2011) and Wang et al. (2013) and the speculative motive of some market participants as pointed by Shino and Takahashi (2010) are the major limitations of SCDS spreads as a measure of sovereign credit risks. Conversely, supporters of SCDS spreads as a measure of sovereign credit risks have also presented interesting arguments. SCDS spreads is credited for capturing new information about the reference entity in a very timely manner as compared to other alternative measures such as sovereign bond spread. Moreover, as indicated by Buchholz and Tonzer (2013), the high liquidity of the SCDS contracts makes it free from liquidity risks and inflation risks as opposed to sovereign bond spreads therefore making the SCDS a pure measure of sovereign credit risks. Other papers further show that SCDS spreads is a better substitute for sovereign ratings assigned by rating agencies as a proxy for sovereign credit risks. The strength of CDS as compared to rating by rating agencies was revealed during the great financial crises of 2008 - 2009. According to Flannery et al. (2010) the rating agencies did not revise the ratings of some U.S. corporations such as Lehman Brothers even up to September 15, 2008 when it filed for bankruptcy, it was still in an investment grade A but the CDS had changed drastically over the period of about one year from 25 basis points in January 2006 to 703 basis points in September 15, 2008. The paper concludes that CDS is a better alternative measure of sovereign credit risks as compared to ratings issued by rating agencies.

\section{Data Description and Methodology}

The analysis is based on sovereign credit default swap premiums data obtained from Reuters. A CDS is a financial derivative instrument that was invented by JP Morgan and was first traded in 1994. At a very basic level it is a contract between two parties usually a buyer and a seller where a buyer makes some regular payment called premiums to a seller in exchange of a contingent payment by the seller in the event that the reference entity defaults on its obligation. In principle, according to many literatures on credit derivative, the CDS contract is similar to an insurance contract in the sense that the buyer is in reality buying protection 
cover against the risk of default by the reference entity. Since the buyer of a CDS is transferring the risks of default to the CDS seller, the buyer has to make some payment called premium to the seller for taking the risk. Hence the price of a CDS contract is called premium. However, if the reference entity does not default up to the time of the expiry of the contract, the protection seller shall not make any payment to the buyer. The seller of the CDS contract will therefore charge the buyer a premium which takes into account the likelihood that the reference entity is going to default (probability of default) and the loss that will be suffered in the event of default (Loss Given Default). For this matter, CDS premium is therefore a good measure of credit risk of a reference entity. If the reference entity is a country, it is called sovereign credit default swap premium. The empirical analysis in this paper are based on daily SCDS premiums obtained from Reuters ranging from January 1, 2013 to November 3, 2015 for the following countries Japan, Malaysia, Indonesia, Thailand, Vietnam and Philippines. These countries are chosen based on SCDS spreads data availability on Reuter's data stream as on April 2016. The sovereign CDS premiums for 5 years contracts denominated in U.S. dollars are considered appropriate for its liquidity. The following methodological analysis now follows:

The Model: The paper used the VAR model for granger causality test and it is assumed that the SCDS premiums for these countries will not attain a long run equilibrium that is, they will not co integrate and hence the paper does not apply error correction mechanisms but instead used a simple VAR model. The bivariate VAR model for granger causality tests on a pair-wise basis for first differenced SCDS premiums of any two countries $\mathrm{X}$ and $\mathrm{Y}$ is specified as below;

$$
\begin{gathered}
\Delta \mathrm{Ycds}_{\mathrm{t}}=\lambda_{1}+\sum_{\mathrm{i}=1}^{5} \alpha_{1 \mathrm{i}} \Delta \mathrm{Ycds}_{\mathrm{t}-\mathrm{i}}+\sum_{\mathrm{i}=1}^{5} \beta_{1 \mathrm{i}} \Delta \mathrm{Xcds}_{\mathrm{t}-\mathrm{i}}+\varepsilon_{1 t} \\
\Delta \mathrm{Xcds}_{\mathrm{t}}=\lambda_{2}+\sum_{\mathrm{i}=1}^{5} \alpha_{2 \mathrm{i}} \Delta \mathrm{Ycds}_{\mathrm{t}-\mathrm{i}}+\sum_{\mathrm{i}=1}^{5} \beta_{2 \mathrm{i}} \Delta \mathrm{Xcds}_{\mathrm{t}-\mathrm{i}}+\varepsilon_{2 \mathrm{t}} \\
\Delta \mathrm{Ycds}_{\mathrm{t}}=\mathrm{Ycds}_{\mathrm{t}}-\mathrm{Ycds}_{\mathrm{t}-1} \\
\Delta \mathrm{Xcds}_{\mathrm{t}}=\mathrm{Xcds}_{\mathrm{t}}-\mathrm{Xcds}_{\mathrm{t}-1}
\end{gathered}
$$

First differences were taken as shown in equation 3 and 4 above to induce stationarity of the SCDS premiums. Wald test was then performed on coefficients of $X$ and $Y$ in equations 1 and 2 to ascertain if $X$ can cause $Y$ or $Y$ can cause $X$. Example if $X$ cannot granger cause $Y$, it implies that coefficients $\beta_{1 i}(i=1,2,3,4,5)$ are zero. Hence the null hypothesis of $\mathrm{X}$ not granger- causing $\mathrm{Y}$ is set as follows:

$$
H_{0}: \beta_{11}=\beta_{12}=\beta_{13}=\beta_{14}=\beta_{15}=0
$$

If the null hypothesis above is true it implies that equation 1 will just be restricted to lagged values of $Y$ alone as independent variables and can just be expressed as below:

$$
\Delta \mathrm{Ycds}_{\mathrm{t}}=\lambda_{1}+\sum_{\mathrm{i}=1}^{5} \alpha_{1 \mathrm{i}} \Delta \mathrm{Ycds}_{\mathrm{t}-\mathrm{i}}+\varepsilon_{1 t}
$$

F statistics is then computed by comparing the error generated by the restricted model in 6 and the error generated by unrestricted model in 1 in order decide if $Y$ can be better predicted by the past value of $Y$ and $X$ rather than the past values of $Y$ alone.

Descriptive Statistics, Trend Analysis and Correlation Analysis: After specifying the modal, important summary statistics such as mean, mode, median, skewness, standard deviation maximum and minimum values were obtained to give the general picture about the status and distribution of SCDS spreads of the countries. The time dynamics of the series were also analyzed in order to identify some interesting patterns of the spreads over time. The so called trend analysis allows for visual inspection of changes in the series overtime and also facilitates comparisons among series. After descriptive analysis, by following Levisauskaite at al. (2014), Pearson's correlation coefficients were computed as a measure of co-movement between SCDS of any two countries. This coefficient is computed as below:

$$
\operatorname{Corr}_{\mathrm{XY}}=\frac{\operatorname{COV}_{\mathrm{XY}}}{\operatorname{VAR}_{\mathrm{X}} \operatorname{VAR}_{\mathrm{Y}}}
$$

Hence correlation between $\mathrm{X}$ and $\mathrm{Y}$ is expressed as the ratio of covariance between $\mathrm{X}$ and $\mathrm{Y}$ to the product of variances of $X$ and $Y$. The Pearson's correlation coefficient $r$, ranges from 0 to 1 and by convention if $r \leq 0.3$, the correlation (co-movement) is weak, for $0.4 \leq r \leq 0.6$, the correlation is moderate and $0.7 \leq r \leq 1$

Stationarity Test: Before proceeding to parametric test of granger causality, the data was tested for Stationarity in order to avoid the consequences of spurious regression. By definition a time series variable is said to be weakly stationary if its expected value and population variance are independent over time and if population covariance between its values at time $t$ and $t+s$ depends on $s$ but not on time. The formal test used here is Augmented Dickey Fuller (ADF) test. It is based on the investigation of the presence of a unit 
root. Using a lag length of 5 in the ADF model in equation 8 below, the hypothesis about stationarity of the series was tested.

$$
\Delta Y_{t}=\mu+\Psi Y_{t-1}+\sum_{i=1}^{5} \alpha_{i} Y_{t-i}+\gamma_{t}+e_{t}
$$

The ADF test was used to test the following hypothesis about the parameter $\Psi$ in the above ADF model where both trend and intercept are included;

$$
\begin{gathered}
H_{0}: \Psi=0 \text { (The data is not stationary, it has a unit root) } \\
H_{1}: \Psi<0 \text { (The data is stationary, it has no unit root) }
\end{gathered}
$$

When the test was conducted at level, the ADF test failed to reject the null hypothesis but at first difference, the data was tested to be stationary and was therefore fit for use in the VAR model for granger causality test.

Lag Length Selection: The next step was to decide on the lag length to be used for testing Granger Causality test within the framework of the VAR model. Parameters in the VAR model are very sensitive to the number of lags chosen and as a general guideline; the optimal lag length is always chosen by minimizing certain criteria such as AIC, SIC, BIC etc. This paper however, follows Nordern and Weber (2007) that suggests the use of five lags for daily CDS data.

Granger Causality Tests: Toda and Phillips (1994) propose that for any two given variables X and Y, if Y can be better predicted using the past values of $X$ and $Y$ than it can be predicted using the past values of $Y$ alone, or if $\mathrm{X}$ is the possible cause of $\mathrm{Y}$, then $\mathrm{X}$ is said to granger cause $\mathrm{Y}$ and vice versa. The logic behind this test is that the past can predict the future but the future cannot predict the past and the present. Hence if $X$ granger causes $Y$ we would expect $X$ to occur first and then followed by Y. Granger causality test was conducted on time series SCDS spreads in a bivariate setting to identify whether series X (for a given country) can be a better predictor of $Y$ (for another country) and vice versa. The test can also provide evidence if $X$ precedes $Y$ or if movements are contemporaneous. Specifically, this test was conducted to establish the sources and direction of causalities of SCDS spreads. The notion of granger causality does not imply true causality but rather identifies the precedence relationship between time series variables.

\section{Empirical Results}

Descriptive Statistics: As seen in table 1 below, on average, Vietnam SCDS spread of 220.141 basis points was the highest among all countries while that of Japan at 30.667 basis points remains the lowest in the sample. The spreads for Indonesia seems to be the most volatile as indicated by the highest standard deviation of 37.698 while Japans SCDS spreads is the most stable one having the standard deviation of only 5.993. For all countries there is evidence that the spreads are not symmetrically distributed given the fact that the coefficients of skewness are not approximately equal to zero. However, the spreads for Japan with 0.336 nearly approaches symmetry. The absence of symmetry indicates the presence extreme values in the data. These extreme values may be attributed to rare events that a country may experience at a given time.

Table 1: Descriptive Statistics for SCDS spreads in Basis Points

\begin{tabular}{lccllll}
\hline & IND & JAP & MAL & PHIL & THAI & VT \\
\hline Mean & 176.536 & 30.667 & 112.022 & 100.785 & 112.129 & 220.141 \\
Max & 288.919 & 48.429 & 239.860 & 153.95 & 174.61 & 305.589 \\
Min & 121.004 & 20.679 & 67.092 & 79.469 & 81.789 & 179.670 \\
Std Dev & 37.698 & 5.993 & 31.732 & 13.631 & 20.453 & 29.418 \\
Skewness & 0.749 & 0.336 & 1.452 & 1.090 & 0.627 & 0.815 \\
\hline
\end{tabular}

As seen in figure 1 below, trend analysis of the behaviors of SCDS of these countries further reveals that the SCDS of Vietnam has always been the highest since 2013 followed by that of Indonesia. Towards the third quarter of 2013, the SCDS spreads of all countries rose up dramatically with that of Vietnam reaching a high of about 305 basis points. The dramatic rise in SCDS spreads might have been due to the effects of sovereign debt crises in Eurozone countries especially the GIIPS countries. Towards the end of 2015, all the SCDS spreads again rose to almost their levels in 2013. The trend in figure 1 further provides evidence that SCDS of ASEAN countries co-move with each other. It can also be seen that Japan's SCDS does not only remains low but is also very stable. The low and stable Japan's SCDS spreads is consistent with the low and stable Japan's government bond yield as noted by Hoshi and Ito (2014). 
Figure 1: Dynamics of SCDS spreads over the sample period

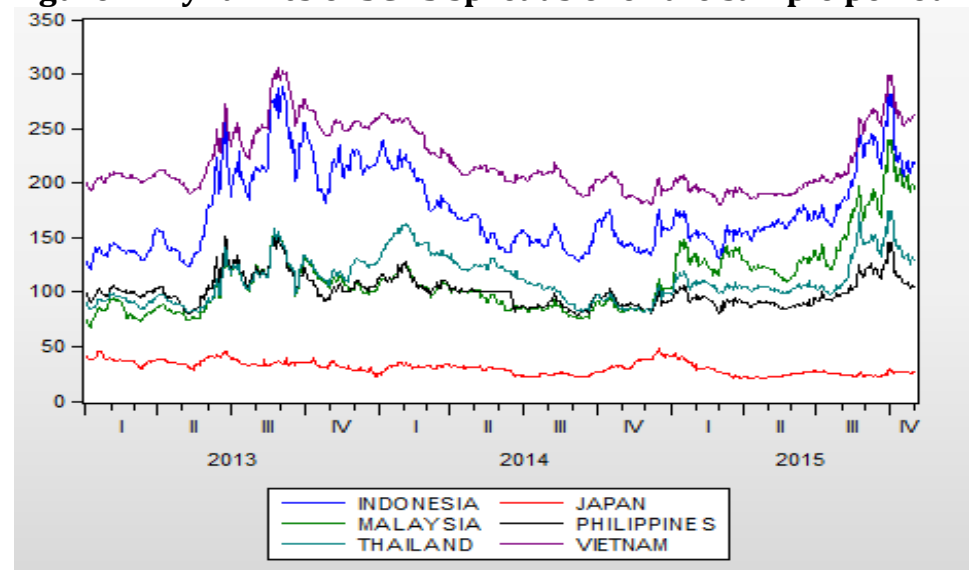

Results of Pearson's Correlation Analysis: As seen in table 2, the high positive correlations are noted among ASEAN countries. Example correlation between Indonesia and other ASEAN countries remains relatively high with the highest being that of Indonesia and Vietnam at 0.9322 . Other strong positively correlated SCDS are that of Philippines and Vietnam at 0.8638, Indonesia and Philippines at 0.8518. In the sense of Barberis et al. (2002), these high correlations suggest that the SCDS of ASEAN countries strongly comove with each other's. Consistent with Cho et al. (2014), correlation analysis reveals that Japan's SCDS does not co-move with those of ASEAN countries as shown by very weak positive correlations and in fact negative correlations are noted between Japan vs. Malaysia and Japan vs. Thailand.

Table 2: Results of Pearson's Correlation Analysis

\begin{tabular}{lllllll}
\hline & IND & JAP & MAL & PHIL & THAI & VT \\
\hline IND & 1.0000 & & & & & \\
JAP & 0.0236 & 1.0000 & & & & \\
MAL & 0.6602 & -0.2689 & 1.0000 & & & \\
PHIL & 0.8518 & 0.2924 & 0.5268 & 1.0000 & & \\
THAI & 0.8047 & -0.1196 & 0.6500 & 0.7437 & 1.0000 & \\
VT & 0.9322 & 0.1145 & 0.5158 & 0.8638 & 0.7847 & 1.0000 \\
\hline
\end{tabular}

Results of Stationarity test at level: As seen in table 3 below, the series were not stationary for all countries given the high $\mathrm{p}$ values for all countries except that of Philippines that was significant at $10 \%$ level. The total number of observations in the sample was 735 for each country. All series including that of Philippines were differenced to ensure they are all stable at $1 \%$ level of significance ( $p$ value $=0.0000$ ) as shown in table 4 . The stationary series permits granger causality tests

Table 3: Results of Stationarity test at level

\begin{tabular}{llll}
\hline Series & P value & Lag & N \\
\hline Indonesia & 0.3783 & 5 & 735 \\
Japan & 0.1984 & 5 & 735 \\
Malaysia & 0.6449 & 5 & 735 \\
Philippines & 0.0960 & 5 & 735 \\
Thailand & 0.3205 & 5 & 735 \\
Vietnam & 0.7376 & 5 & 735 \\
\hline
\end{tabular}

$\mathrm{N}=$ the number of observations in the sample 
Table 4: Results of Stationarity test after first difference

\begin{tabular}{llll}
\hline Series & P value & Lag & N \\
\hline Indonesia & 0.0000 & 5 & 734 \\
Japan & 0.0000 & 5 & 734 \\
Malaysia & 0.0000 & 5 & 734 \\
Philippines & 0.0000 & 5 & 734 \\
Thailand & 0.0000 & 5 & 734 \\
Vietnam & 0.0000 & 5 & 734 \\
\hline
\end{tabular}

Results of Granger Causality Tests: As seen in table 5 and figure 2 below, unidirectional causalities from ASEAN countries to Japan are detected, in other words, the sovereign credit default swap spreads of ASEAN countries granger-cause Japan's SCDS spreads. This indicates that the SCDS spreads of ASEAN countries lead those of Japan. This situation means that ASEAN countries SCDS cannot be better predicted by past values of Japan's SCDS. All ASEAN countries granger caused Japan either at $1 \%$ level $(*)$, or at $5 \%$ level $\left(^{* *}\right.$ ) of significance. Within ASEAN countries unidirectional causalities have been seen originating especially from Indonesia to all ASEAN countries. In the same way, this provides some evidence that the SCDS spreads of Indonesia lead those of ASEAN countries. However, no causality is detected between Malaysia and Philippines, Malaysia and Vietnam and finally between Philippines and Thailand. Only one bidirectional causality between Philippines and Vietnam is detected at 5\% level. The findings of this paper is related to the findings of Guimaraes and Hong (2016) which reveals that developed economies like Japan are no longer giver of shocks to other countries but instead emerging economies in Asia example China and Korea are the major propellers of shocks to other countries. Furthermore, it is consistent with Cho, Choi and Chung (2014) which concludes that the SCDS of Japan does not co-move with those of other Asian countries. Finally it is similar to Yoshizaki et al. (2013) which studies the SCDS of Japan and other European countries and found no transmission effects from Japan to European countries especially before the crises. The implication of these results is that whenever we see changes in sovereign credit risks of Japan measured by its SCDS spreads, we should not expect the sovereign credit risk of ASEAN countries to change. Figure 2 below shows directions of causalities among SCDS of ASEAN countries and Japan at 1\% and 5\% levels respectively

Figure 2: Illustration of Results of Granger Causality Tests

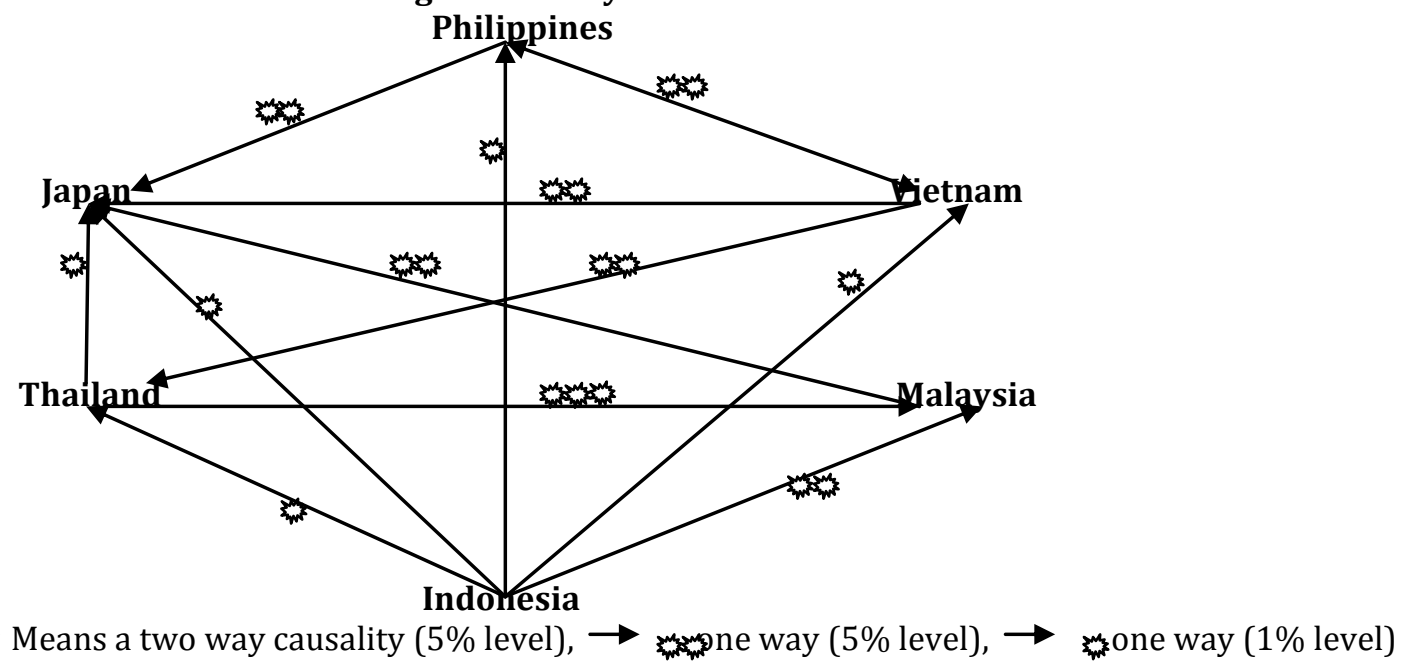


Table 5: Results of Granger Causality test

\begin{tabular}{|c|c|c|c|c|}
\hline NO & Pairs of Countries & Chi Square & P value & Direction of Causality \\
\hline \multirow[t]{2}{*}{1} & D(Indonesia) & 16.106 & 0.0065 & Unidirectional* \\
\hline & D(Japan) & 6.556 & 0.2556 & Indonesia $\rightarrow$ Japan \\
\hline \multirow[t]{2}{*}{2} & D(Malaysia) & 14.306 & 0.0138 & Unidirectional ${ }^{* *}$ \\
\hline & D(Japan) & 7.659 & 0.1760 & Malaysia $\rightarrow$ Japan \\
\hline \multirow[t]{2}{*}{3} & D(Philippines) & 14.391 & 0.0133 & Unidirectional** \\
\hline & D(Japan) & 2.257 & 0.8125 & Philippines $\rightarrow$ Japan \\
\hline \multirow[t]{2}{*}{4} & D(Thailand) & 14.116 & 0.0149 & Unidirectional* \\
\hline & D(Japan) & 7.604 & 0.1794 & Thailand $\rightarrow$ Japan \\
\hline \multirow[t]{2}{*}{5} & $\mathrm{D}($ Vietnam) & 11.170 & 0.0481 & Unidirectional ** \\
\hline & D(Japan) & 6.864 & 0.2309 & Vietnam $\rightarrow$ Japan \\
\hline \multirow[t]{2}{*}{6} & D(Malaysia) & 4.295 & 0.5077 & Unidirectional $^{* *}$ \\
\hline & $\mathrm{D}$ (Indonesia) & 13.476 & 0.0193 & Indonesia $\rightarrow$ Malaysia \\
\hline \multirow[t]{2}{*}{7} & D(Indonesia) & 45.201 & 0.0000 & Unidirectional* \\
\hline & D(Philippines) & 7.452 & 0.1891 & Indonesia $\rightarrow$ Philippines \\
\hline \multirow[t]{2}{*}{8} & D(Indonesia $)$ & 22.877 & 0.0004 & Unidirectional* \\
\hline & $\mathrm{D}$ (Thailand) & 8.225 & 0.1442 & Indonesia $\rightarrow$ Thailand \\
\hline \multirow[t]{2}{*}{9} & D(Indonesia) & 27.612 & 0.0000 & Unidirectional* \\
\hline & $\mathrm{D}($ Vietnam $)$ & 1.599 & 0.9013 & Indonesia $\rightarrow$ Vietnam \\
\hline \multirow[t]{2}{*}{10} & D(Malaysia) & 4.516 & 0.4777 & No Causality \\
\hline & D(Philippines) & 2.995 & 0.7007 & \\
\hline \multirow[t]{2}{*}{11} & D(Malaysia) & 4.675 & 0.4567 & Unidirectional $^{* * *}$ \\
\hline & D(Thailand) & 10.380 & 0.0651 & Thailand $\rightarrow$ Malaysia \\
\hline \multirow[t]{2}{*}{12} & D(Malaysia) & 1.422 & 0.9218 & No Causality \\
\hline & $\mathrm{D}($ Vietnam $)$ & 4.419 & 0.4908 & \\
\hline \multirow[t]{2}{*}{13} & D(Philippines) & 7.950 & 0.1590 & No Causality \\
\hline & D(Thailand) & 2.900 & 0.7154 & \\
\hline \multirow[t]{2}{*}{14} & D(Philippines) & 11.728 & 0.0380 & Bidirectional** \\
\hline & $\mathrm{D}($ Vietnam $)$ & 22.333 & 0.0005 & Vietnam $\leftrightarrow$ Philippines \\
\hline \multirow[t]{2}{*}{15} & D(Thailand) & 4.152 & 0.5272 & Unidirectional** $^{*}$ \\
\hline & $\mathrm{D}($ Vietnam) & 11.397 & 0.0441 & Vietnam $\rightarrow$ Thailand \\
\hline
\end{tabular}

* Means $1 \%$ significance level, ${ }^{* *}$ Means $5 \%$ significance ${ }^{* * *}$ Means $10 \%$ level

$\rightarrow$ Direction of one- way causality, $\leftrightarrow$ Shows causality with feedback

Business and Policy Implications: The general results of granger causality tests and correlation analysis indicates that there is little evidence of co-movements between Japan's sovereign credit risks with those of ASEAN countries as indicated by the weak positive correlation coefficients and at some points negative correlation coefficients between Japan and these countries are noted. Granger causality tests further reveal 
that Japan's SCDS spreads are not a better predictor of ASEAN countries spreads. Since Japan's sovereign credit risks and ASEAN countries sovereign credit risks are uncorrelated (do not commove), from investors perspective this can be a good opportunity to minimize portfolio risk of investment by diversifying investment in the sovereign bonds of Japan and ASEAN countries since the credit risks of these bonds do not move in the same direction. It may also suggest that when evaluating the performance of ASEAN countries sovereign bond market, the macroeconomic and financial situations of Japan may not be considered a major factor because the sovereign credit risk situation in Japan cannot better predict the sovereign credit risks of ASEAN countries. Conversely, ASEAN sovereign credit risks can better predict the sovereign credit risk of Japan as indicated by unidirectional casualties from these countries. Investors in Japanese bonds should be concern about the fiscal and the overall macro-economic situations in ASEAN countries as they invest in Japanese government bonds. Japan's policy makers should also take into consideration the macroeconomic situation in ASEAN as they make forecasts for the performance of Japanese economy.

On the other hand, it appears that the sovereign credit risks within ASEAN countries are highly synchronized and move together as indicated by results of correlation analysis, unidirectional granger causalities and bidirectional granger causality between Philippines and Vietnam. From investment point of view this situation makes portfolio investment in ASEAN sovereign bonds appears like putting all the eggs in one basket. Policy makers for these countries should try to identify areas of commonalities in their sovereign balance sheet and try to coordinate their policies accordingly. The high sovereign credit risk co-movement among these ASEAN countries may also render government guarantee schemes for loans to SMEs ineffective. These schemes are used in Thailand and many Asian countries to enable SMEs access finance from banks since they do not have collaterals needed by banks. The high sovereign credit risk co-movement in the region implies that banks may start evaluating the sovereign credit worthiness of individual countries basing on the regional outlook not individual country's sovereign credit worthiness. Unfortunately, other countries like Vietnam and Indonesia already appear to be risky sovereigns and in fact Vietnam sovereign bond is already rated in the speculative grade by rating agencies. The high sovereign credit risk co-movement example between Vietnam to Thailand may induce banks in Thailand not to honor Thailand's guarantee scheme for SMEs in Thailand. It is advisable for banks not to honor such schemes in sovereigns which appear to be more risky like Vietnam and Indonesia because through those guarantee schemes, sovereign credit risk can find its ways into banks' balance sheets and may culminate into banking crises with more devastating effects on the economy.

\section{Conclusion}

This paper studies the causal linkages between the sovereign credit risks of Japan and selected ASEAN countries and used different analysis such as descriptive statistics, correlation analysis, trend analysis and granger causality tests using bivariate VAR model. It also examines the causal linkages of sovereign credit risks among these ASEAN countries themselves. By visual inspection and analysis of descriptive statistics, Japanese spread has been the most stable and the lowest indicating the low and stable sovereign credit risks level of Japan compared to other countries under study. Conversely, Vietnamese spread has always been the highest over the study period and Indonesia's spreads the most volatile. This point out that Vietnam is the most risky sovereign bond among the sampled countries. The paper follows the theory which is well established in literature that sovereign credit default swap spreads is a good proxy for sovereign credit risk, and sovereign credit risks on the other hand can generate a number of negative externalities for private businesses in the host country. The paper finds that while co-movement among ASEAN countries SCDS spreads is very strong, The SCDS of Japan on the other hand do not co-move with those of ASEAN. Results of granger causality test indicate all ASEAN countries granger cause Japan at different levels of significance while Japan fails to granger cause all these countries. This thus implies that Japan's sovereign credit risks is not a better predictor of the ASEAN countries sovereign credit risks while on the other hand, the sovereign credit risks of ASEAN countries are better predictor of the sovereign credit risks of Japan. 


\section{References}

Afonso, A., Gomez, P. M. \& Rother, P. (2007). What hides behind sovereign debt rating? European Central Bank Working Paper, No.711.

Ang, A. \& Longstaff, F. A. (2013). Systemic sovereign credit risk: Lesson from the U.S. and Europe. Journal of Monetary Economics, 60(5), 493-510.

Barberis, N., Shleifer, A. \& Wurgler, J. (2002). Co movement. National Bureau of Economic Research Working Paper, No.711.

Bucholz, M. \& Tonzer, L. (2013). Sovereign credit risks co-movement in Eurozone: Simple interdependence or contagion? Unicredit and Universities Foundation Working Paper Series, No. 47/13

Cabalu, H. (2000). A Review of Asian Crisis: Causes, consequences, and policy implications. The Australian Economic Review, 32(3), 304-313

Cantor, R. \& Packer, F (1996). Determinants and impacts of sovereign credit ratings. Economic Policy Review, $2(2)$.

Cho, D., Choi, K. \& Chung, K. (2014). Interconnectedness and contagion effects in Asian sovereign CDS markets. Working Paper.

Coronado, M., Corzo, M. T. \& Lazcano, L. (2012). A case of Europe: The relationship between sovereign CDS and stock indexes. Frontiers in Finance and Economics, 9(2), 32-63.

Coudert \& Gex. (2013) .The interactions between credit default swaps and bond market in financial turmoil. Review of International Economics, 21(3), 492-502.

Das, U. S., Oliva, M. A. \& Tsuda, T. (2012). Sovereign risks: A macro -financial perspective. ADBI Working Paper Series, No. 383.

Diebold, F. X. \& Yilmaz, K. (2009). Measuring financial assets return and volatility spillovers, with application to global equity markets. Economic Journal, 119, 158 - 171

Ding, L. (2010). U.S. and Asian Pacific equity market causality test. International Journal of Business and Management, 5(9).

Doi, T. \& Okimoto, T. (2011). Japanese government debt and sustainability of fiscal policy. Journal of the Japanese and International Economies, 25(4), 414 - 433

Duval, R., Cheang, K., Oh, K. H., Saraf, R. \& Seneviratne, D. (2014). Trade integrations and business cycle synchronization: A reappraisal with focus on Asia. I.M.F Working Paper, No. WP/14/52

ECONOTE. (2013). Rising public debts in Japan: How far is too far? Societe Generale, Department of Economics studies No. 21/November 2013

Ertugrul, H. M. \& Ozturk, H. (2013). The drivers of credit default swap prices: Evidence from selected emerging markets. Emerging Markets Finance \& Trade, 49, 228 - 249

Eyssell, T., Fung, H. G. \& Zhang, G. (2013). Determinants and price discovery of China sovereign credit default swap. China Economic Review, 24, 1-15

Flannery, M. J., Houston, J. F. \& Partnoy, F. (2010). Credit default swap spreads as viable substitutes for credit ratings. University of Pennsylvania Law Review, 2, 2085 - 2123

Fontana, A. \& Scheicher, M. (2010). An analysis of Euro area sovereign CDS and their relation with government bonds. European Central Bank Working Paper, No. 1271

Gapen, M. T., Gray, D. F., Lim, C. H. \& Xiao, Y. (2005). Measuring and analyzing sovereign risks with contingent claims. IMF Working paper, No. wp/05/155

Gelos, G. \& Sahay, R. (2000). Financial market spillover in transition economies. IMF working paper $\mathrm{wp} / 00 / 71$

Guimaraes, R. \& Hong, G. H. (2016). Dynamics connectedness of Asian equity markets. IMF working paper, No. WP/16/57

Gunduz, Y. \& Kaya, O. (2013). Sovereign default swap market efficiency and country risk in Eurozone. Deutsche Bundesbank Discussion Paper, No. 08/2013

Hatchondo, J. C., Martinez, L. \& Sapriza, H. (2007). The economics of sovereign default. Economics Quarterly, 93(2), 163-187

Heinz, F. F. \& Sun, Y. (2014). Sovereign CDS spreads in Europe: The role of global risk aversion, economic fundamentals, liquidity and spillover. IMF working paper, No. wp/14/17

Hoshi, T. \& Ito, T. (2014). Defying the Gravity: Can Japanese sovereign debt continue to increase without a crisis? Economic Policy, 29(77), 5-44 
International Monetary Fund. (2011). Assessing the risks to the Japanese Government Bond (JGB) Market. IMF Working Paper, No. WP/11/292

International Monetary Fund. (2011). Japan: 2011 Article IV Consultation. IMF Country Report, No 11/181

Ito \& Takatoshi. (2011). Sustainability of Japanese sovereign debt. ERIA project http;//eria.org/research/y2010-no 1.html

Jakpar, S. \& Vejayon, V. (2013). An econometric analysis on the co-movement of stock market volatility between China and ASEAN-5. International Journal of Business and Social Science, 4(14).

Kalotychou, E., Remolona, E. \& Wu, E. (2013). Intra-regional credit contagion and global systemic risk in international sovereign debt Markets. Hong Kong Institute of Monetary Research

Kawai, M., Thuzar, M. \& Hayton, B. (2016). ASEAN's regional role and relations with Japan: Challenges of deeper integration. Research paper, Chatham House.

Kregzde, A. \& Marauskas, G (2015). Analyzing sovereign default swaps of Baltic countries. Business: Theory and Practice, 16(2), 121-131.

Lestano \& Kuper, G. H. (2016). Correlation dynamics in East Asian financial markets. Emerging Markets Finance \& Trade, 52(2), 382-399.

Levy, A. (2009). The CDS bond basis spreads in emerging markets: Liquidity and counterparty risks effects. Working paper.

Levisauskaite, K., Alekneviciene, V. \& Alekneviciute, E. (2014). Co-movement of financial markets in the EU Countries. Engineering Economics, 25(4), 261-272.

Longstaff, F. A., Pan, J., Pedersen, L. H. \& Singleton, K. J. (2011). How sovereign is sovereign credit risk? American Economic Journal, Macroeconomics, 3, 75-103.

Norden, L. \& Weber, M. (2007). The co-movement of credit default swap, bond and stock markets: An empirical analysis. European Financial Management, 15(3), 529 - 562

Robinson, Z. (2015). An analysis of sovereign risk in South Africa with the focus on fiscal determinants. Southern African Business Review, 19(3), 154-174.

Sakuragawa, M. \& Hosono, K. (2011). Fiscal sustainability in Japan. Journal of the Japanese and International Economies, 25(4), 434-446.

Shino, J. \& Takahashi, K. (2010). Sovereign credit default swap: Market developments and factors behind price changes. Bank of Japan Review, 2, 1-9.

Stolbov, M. (2014). The causal linkages between sovereign CDS prices for the BRICS and major European Economies. Open-assessment E-Journal, 8, 14 -26.

Toda, H. Y. \& Phillips, P. C. (1994). Vector auto regression and causality: A theoretical overview and simulation study. Econometric reviews, 13(2), 259-285.

Wang, A. T., Yang, S. Y. \& Yang, N. T. (2013). Information transmission between sovereign debt CDS and other financial factors: The case of Latin America. The North American Journal of Economics and Finance, 26, 586-601.

Yoshizaki, Y., Toyoshima, Y. \& Haomori, S. (2013). The causal relationship between sovereign CDS premium for Japan and selected EU countries. Applied Economic Letters, 20, 742-747. 